\title{
Effects on Survival of Escherichia coli O157:H7 in Non-Intact Steaks of the Frequency of Turning Over Steaks During Grilling
}

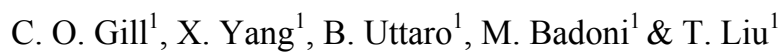 \\ ${ }^{1}$ Agriculture \& Agri-Food Canada, Lacombe Research Centre, Lacombe, Canada \\ Correspondence: C. O. Gill, Agriculture \& Agri-Food Canada, Lacombe Research Centre 6000 C \& E Trail, \\ Lacombe, AlbertaT4L 1W1, Canada. Tel: 1-403-782-8113. E-mail: colin.gill@agr.gc.ca
}

Received: July 14, 2013

Accepted: August 19, 2013 Online Published: August 23, 2013

doi:10.5539/jfr.v2n5p77

URL: http://dx.doi.org/10.5539/jfr.v2n5p77

\begin{abstract}
Beef steaks between $1 \mathrm{~cm}$ and $3 \mathrm{~cm}$-thick were inoculated with Escherichia coli $\mathrm{O} 157: \mathrm{H} 7$ and/or temperature histories were collected at steak centres, at points initially below the central plane, and/or at points $1 \mathrm{~cm}$ or $2 \mathrm{~cm}$ from steak edges. The steaks were turned over once during grilling when temperatures at the centres reached $30^{\circ} \mathrm{C}$ or $50^{\circ} \mathrm{C}$, or at specified times once, twice or several times during cooking to specified temperatures between 60 and $71^{\circ} \mathrm{C}$. When steaks were turned over at centre temperature of 30 or $50^{\circ} \mathrm{C}$, some points in some steaks did not reach the temperatures specified for steak centres. When steaks turned over at $50^{\circ} \mathrm{C}$ were cooked to 60,63 or $65^{\circ} \mathrm{C}, E$. coli $\mathrm{O} 157: \mathrm{H} 7$ inoculated at $\geq 5 \log$ cfu at each point survived at some points in some steaks at numbers $\geq 3 \log \mathrm{cfu}$. When steaks were turned over once during cooking to $71^{\circ} \mathrm{C}$, E. coli $\mathrm{O} 157: \mathrm{H} 7$ survived at some points in some steaks turned over after $\leq 8 \mathrm{~min}$. When steaks were turned over frequently, or twice at appropriate times during cooking to $63^{\circ} \mathrm{C}$, no E. coli $\mathrm{O} 157: \mathrm{H} 7$ were recovered from any inoculated steak. Thus, cooking steaks to $71^{\circ} \mathrm{C}$ may sometimes have only relatively small effects on $E$. coli $\mathrm{O} 157: \mathrm{H} 7$ in steaks turned over once. However, turning steaks over twice or more during cooking to $63^{\circ} \mathrm{C}$ can ensure inactivation of large numbers of $E$. coli $\mathrm{O} 157: \mathrm{H} 7$ at all points in mechanically tenderized steaks.
\end{abstract}

Keywords: beef steaks, mechanically tenderized beef, cooking, Escherichia coli O157:H7

\section{Introduction}

Much beef in the forms of steak or roast that is sold at retail stores or prepared at restaurants in North America has been mechanically tenderized (Clyma, 2013). Most mechanical tenderizing treatments involved repeated incision of beef primal cuts with banks of needles or thin blades (Maddock, 2008). Tenderizing treatments are carried out at beef packing and processing plants, at the meat processing facilities of retail stores and at restaurants (Gill, McGinnis, Rahn, Young, Lee, \& Barbut, 2005; Jeremiah, Gibson, \& Cunningham, 1999).

Mechanical tenderizing treatments will result in some of the bacteria on beef surfaces being carried into the previously sterile deep tissues (Gill \& McGinnis, 2004; Johns, Bratcher, Kerth, \& McCaskey, 2011). Bacteria carried into the deep tissues may include pathogenic organisms such as Salmonella or verotoxigenic Escherichia coli (VTEC). If the meat is cooked to a less than well done condition, pathogens in the deep tissues may survive to infect consumers. In this respect, VTEC of the O157:H7 or O157:NM serotypes are of the greatest concern, because of their low infectious doses and the often serious and sometimes fatal consequences of O157 VTEC infections (Pennington, 2010).

An early evaluation of the increased risks to human health that would result from mechanical tenderizing of beef found that any increases would be small (US Department of Agriculture, Food Safety and Inspection Service, USDA/FSIS, 2002). This evaluation was apparently supported by the few outbreaks of E. coli O157 illness associated with tenderized beef that were reported in subsequent years (Laine et al., 2005). However, in recent years, two outbreaks of E. coli $\mathrm{O} 157$ illness associated with consumption of mechanically tenderized beef have been reported (Centers for Disease Control and Prevention, 2011; Lewis, Corriveau, \& Usborne, 2013). These outbreaks, in which there were a total of 26 reported illnesses but no deaths, prompted regulatory authorities to re-evaluate the risk to consumers from E. coli O157 in tenderized beef (Catford et al., 2013; USDA/FSIS, 2012). Those risks, while still small, appear to be greater than previously thought. Therefore, regulatory authorities in Canada and the US have determined that all mechanically tenderized beef should be labelled as such; and that the labels should carry cooking instructions that, if followed, will ensure the microbiological safety of the meat 


\section{(Canadian Food Inspection Agency, CFIA 2013; USDA/FSIS, 2013).}

The formulation of appropriate cooking instructions for mechanically tenderized beef presents some difficulties. While cooking the meat to a well done condition throughout would certain render it safe, many consumers prefer that beef be cooked to a less than well done condition (Lopez Osornio, Hough, Salvador, Chambers, McGraw, \& Fiszman, 2008). To address consumer preferences, cooking instructions should then identify the minimal cooking consistent with assurance of microbiological safety.

Appropriate cooking instructions for mechanically tenderized roasts are readily apparent, because heating is applied uniformly to the meat surface, the temperature at the centre will be the attained at any point in the roast, and the temperature at the centre will continue to rise after cooking ceases (Obuz, Powell, \& Dikeman, 2002). Appropriate, minimal conditions for cooking steaks are less obvious, because steaks are commonly cooked by grilling one surface at a time, culinary instructions commonly recommend that steaks be turned only once during cooking, and times suggested for cooking steaks before they are turned vary considerably (Beef Information Centre, BIC, 2009; Johnson, 2010; Meat and Livestock Australia, MLA, 2006; What's cooking America, WCA, 2012).

US regulatory authority have suggested that the microbiological safety of mechanically tenderized steaks can be assured by cooking to $71^{\circ} \mathrm{C}$, or $63^{\circ} \mathrm{C}$ with holding for $3 \mathrm{~min}$ after cooking ends (USDA/FSIS, 2013). However, the few studies of inactivation of $E$. coli $\mathrm{O} 157: \mathrm{H} 7$ in inoculated mechanically tenderized steaks found large variations in inactivation of the pathogen with replicated cooking of steaks (Luchansky, Porto-Fett, shoyer, Phebus, Thippareddi, \& Call, 2009; Luchansky et al., 2012; Patel, William-Cambell, Liu, \& Solomon, 2005). These studies all involved steaks being turned over only once during grilling. It is then possible that when steaks are turned over only once, cooking to $71^{\circ} \mathrm{C}$ at the centre may not always ensure that all points in a steak experience temperatures that give adequate inactivation of E. coli $\mathrm{O} 157: \mathrm{H} 7$. Moreover, if some points in steaks cool rapidly after reaching temperatures marginal for inactivation of E. coli $\mathrm{O} 157: \mathrm{H} 7$, then holding after cooking ended would not ensure adequate inactivation. Therefore, to allow assessment of the accuracy of currant recommendations studies were performed to determine temperature histories of and survival of inoculated $E$. coli O157:H7 at points other than the centre within steaks turned over once during cooking to various temperatures at the centre.

Whether or not cooking steaks to $71^{\circ} \mathrm{C}$ and turning them over only once during cooking is adequate for inactivating $E$. coli $\mathrm{O} 157: \mathrm{H} 7$, cooking to lower temperature without compromising microbiological safety would still be desirable. Some studies of inactivation of E. coli $\mathrm{O} 157$ in hamburger patties or brine injected steaks have indicated that inactivation of E. coli $\mathrm{O} 157$ may be greater when the items are turned over frequently instead of once during cooking to a less than well done temperature (Gill, Moza, \& Barbut, 2009; Ree, Lee, Hillers, McCurdy, \& Kang, 2003). Reduction of the variation in inactivation by frequent turning might then allow mechanically tenderized steaks to be safely cooked to a lower temperature than would be required if they were turned only once. Therefore, the effects on inactivation of E. coli $\mathrm{O} 157$ of the number of times steaks are turned over during cooking were investigated also.

\section{Materials and Methods}

\subsection{Preparation and Cooking of Steaks}

Vacuum packaged eye of round (semitendinosus) primal cuts that weighed $2.5 \pm 0.3 \mathrm{~kg}$ were obtained from a beef packing plant. Steaks of thickness between $1 \mathrm{~cm}$ and $3 \mathrm{~cm}$, inclusive, were cut from chilled primals as required. After being cut from a primal each steak was placed in a plastic bag and returned to the refrigerator for $15 \mathrm{~min}$ before it was cooked. When steaks were inoculated the inoculation was done before the steaks were returned to the refrigerator. Steaks were cooked singly on a sheet of aluminum foil covering a hot plate (Data-plate, Model No. 720A; Bamstead International, Dubuque, IA, USA). Steaks were cooked with the hot plated operated at 170,200 or $230^{\circ} \mathrm{C}$, with temperatures controlled within $2^{\circ} \mathrm{C}$ of the set temperature. Steaks were turned over during cooking, as required, using tongs with smooth gripping surfaces.

\subsection{Monitoring Steak Temperatures}

With all steaks, temperature probes were inserted into steaks to record temperatures from the centres before steaks were cooked. With most steaks, probes were inserted at the same time to record temperatures from points in the central plane $0.5,1.0$ or $2.0 \mathrm{~cm}$ from the steak edge. With some steaks, temperature probes were inserted into the upper surfaces of steaks before they were cooked to record temperatures at a point $1 \mathrm{~cm}$ horizontally from the centre and $0.5 \mathrm{~cm}$ below the central plane of each steak. These probes were removed immediately before the steaks were turned over. After steaks were turned over the probes were inserted through the surfaces 
that were then uppermost to record temperatures at or close to the points from which temperatures had been recorded before steaks were turned over. With some other steaks, temperature probes were inserted into the surfaces that were uppermost after steaks were turned over, to record temperatures at points in each steak $1 \mathrm{~cm}$ from the steak centre and $0.5 \mathrm{~cm}$ above and $0.5 \mathrm{~cm}$ below the central plane.

Each temperature history was collected using a stainless steel probe that was $20 \mathrm{~cm}$ long and $1.5 \mathrm{~mm}$ in diameter (Catalogue No. U-08505-63; Cole-Parmer Instruments, Vernon Hills, IL, USA). The probe was fitted with a type $\mathrm{T}$ thermocouple sensor with a $10 \mathrm{~s}$ response time. Output from the probe was processed through a thermocouple thermometer (Dualog $\mathrm{R}^{\mathrm{TM}}$; Cole-Parmer) which was connected to a computer to record temperatures at $10 \mathrm{~s}$ intervals. Probes were sterilized by immersion in ethanol followed by flaming before they were inserted into steaks.

\subsection{Preparation of Inocula and Inoculation of Steaks}

The organisms used in the study were 5 strains of non-pathogenic E. coli O157:H7 from the culture collection of the Food Science Department of the University of Manitoba. The strain designations were, 0304, 0627, 0648, 1840 and 3581. The organisms were maintained on slants of nutrient agar (Difco, Becton Dickinson, Sparks, MD, USA). For preparation of inocula, each strain was grown in half strength Brain Heart Infusion (BHI; Difco) overnight, at $35^{\circ} \mathrm{C}$, to the stationery phase. Each culture was suitably diluted in BHI to obtain a suspension containing between $10^{8}$ and $10^{9} \mathrm{cfu} / \mathrm{ml}$. The suspensions were mixed in equal proportions to obtain a 5 -strain cocktail containing $>10^{8} \mathrm{cfu} / \mathrm{ml}$. The cocktail was supplemented with $200 \mathrm{ppm}$ of the food dye FDC Blue \#1 (Calico Food Ingredients, Kingston, Ontario, Canada) by addition of $1 \mathrm{ml}$ of a solution of the dye in BHI.

Steaks were inoculated at selected points by first disrupting tissue at each point to be inoculated, using a sterile toothpick fitted with a collar of plastic tubing to leave uncovered a length off toothpick equal to the required depth of penetration of the meat. The toothpick was inserted vertically into the meat, then rotated around the point of insertion while inclined a few degrees from the vertical. The toothpick was removed, and a mechanical pipette was used to inoculate $10 \mu \mathrm{l}$ of a cocktail into the disrupted tissue at the end of the track created by the toothpick. Previous studies had shown that bacterial suspensions inoculated into intact muscle tissue could disperse into large volumes of tissue (Uttaro, Badoni, Zawadski, \& Gill, 2011). Disruption of the tissue precluded this dispersion. Therefore, the procedure used in this study was adopted to ensure that inocula remained concentrated at selected points in steaks. The soluble dye in the suspension allowed certain location of the entire volume of tissue that contained or had contained the bacteria inoculated at each point.

\subsection{Sampling of Steaks and Enumeration of E. coli O157:H7}

Before inoculated tissue was removed from a cooked steak or a control steak that was not cooked, the surface of the steak was seared to a depth of about $3 \mathrm{~mm}$ by application of a heated stainless steel plate. A portion of meat that weighed about $1 \mathrm{~g}$ and included all dye tissue was excised from each point of inoculation using sterile instruments. The excised tissue was stomached with $10 \mathrm{ml}$ of $0.1 \%$ peptone water. Dilutions of $10^{-2}$ and $10^{-3}$ and all remaining stomacher fluid from each portion of meat from cooked steaks, or dilutions of $10^{-3}$ and $10^{-4}$ of the fluid from each portion from control steaks were each filtered through a hydrophobic grid membrane filter. Each filter was placed on a plate of lactose monensin glucuronate agar (LMG) and incubated at $35^{\circ} \mathrm{C}$ for $24 \mathrm{~h}$. Squares on the filter that contained blue colonies were counted. Coliforms form blue colonies on LMG, and all such organisms recovered from inoculated tissue were assumed to be $E$. coli $\mathrm{O} 157: \mathrm{H} 7$. A most probable number of $E$. coli $\mathrm{O} 157: \mathrm{H} 7$ in the filtered fluid was calculated from the count of squares containing blue colonies using the formula MPN $=\mathrm{N} x \log _{\mathrm{n}}(\mathrm{N} / \mathrm{N}-\mathrm{X})$, where $\mathrm{N}$ is the total number of squares on a filter and $\mathrm{X}$ is the count of squares containing blue colonies.

\subsection{Experimental Procedure}

Four sets of experiments were performed, with a group of 5 steaks being used for each experiment. When one or two groups of steaks were inoculated with the same E. coli $\mathrm{O} 157: \mathrm{H} 7$ cocktail, a further steak was inoculated as were the steaks in the group or groups. This steak was not cooked, but E. coli O157:H7 were recovered from each of the inoculated points to provide a value for the numbers inoculated into steaks that were cooked. Unless otherwise stated, steaks were cooked with the hot plate operating at $200^{\circ} \mathrm{C}$. For the first set of experiments, temperature histories were collected from $3 \mathrm{~cm}$-thick steaks. Temperatures in each steak were monitored throughout cooking and for 5 min after cooking ended at each of points in the centre, and $1 \mathrm{~cm}$ and $2 \mathrm{~cm}$ from the steak edge. Temperatures were monitored after steaks were turned over until $5 \mathrm{~min}$ after cooking ended, from points $1 \mathrm{~cm}$ and $2 \mathrm{~cm}$ below the upper surface. With 4 groups of steaks, the steaks were turned over when the temperature at their centres reached $30^{\circ} \mathrm{C}$. Then all steaks in a group were cooked to $60,65,70$ or $75^{\circ} \mathrm{C}$, with one group being cooked to each temperature. The steaks in 4 further groups were turned over when the temperatures 
at their centres reached $50^{\circ} \mathrm{C}$. Cooking of the steaks was then completed as for steaks turned over when temperatures at their centres reached $30^{\circ} \mathrm{C}$.

Steaks $3 \mathrm{~cm}$ - and $2 \mathrm{~cm}$-thick were used for the second set of experiments. Each steak was inoculated with an $E$. coli $\mathrm{O} 157: \mathrm{H} 7$ cocktail at points in the centre and in the central plane $1 \mathrm{~cm}$ from the edge. Also, steaks that were 3 $\mathrm{cm}$ - or $2 \mathrm{~cm}$-thick were, respectively, inoculated at points $2.0 \mathrm{~cm}$ or $1.5 \mathrm{~cm}$ from the surfaces that were to be uppermost when cooking commenced. Temperature histories were collected from points close to each of the three points inoculated with E. coli $\mathrm{O} 157: \mathrm{H} 7$, throughout the time of cooking of each steak. All steaks were turned over when the temperature at the centre reached $50^{\circ} \mathrm{C}$. A group of steaks of each thickness was cooked to a temperature at the centre of 60,63 or $65^{\circ} \mathrm{C}$. Subsequently, $2 \mathrm{~cm}$-thick steaks were each inoculated with a cocktail of $E$. coli $\mathrm{O} 157: \mathrm{H} 7$ at the centre and at points in the central plane 1.0 and $0.5 \mathrm{~cm}$ from an edge. Temperatures at the steak centre were monitored. When cooking ended, temperatures were determined at 3 points at each of 1.0 and $0.5 \mathrm{~cm}$ from the steak edge, in the central plane. Groups of 5 steaks were turned over after cooking for $2,4,6,8,10$ or $12 \mathrm{~min}$. All steaks were cooked to $71^{\circ} \mathrm{C}$ after turning.

Groups of steaks that were 1.0, 1.5, 2.0, 2.5, or $3.0 \mathrm{~cm}$-thick were inoculated with cultures of E. coli O157:H7. Each steak was inoculated at a point in the centre and at points in the centre line 0.5 and $1.0 \mathrm{~cm}$ from the edge. Temperatures at the centre of each steak were monitored. A group of steaks of each thickness was cooked at $200^{\circ} \mathrm{C}$, to $63^{\circ} \mathrm{C}$. Steaks that were $1.0,1.5,2.0,2.5$ and $3.0 \mathrm{~cm}$-thick were turned over twice during cooking, at intervals of 2, 4, 6, 8 and $10 \mathrm{~min}$, respectively. Groups of $2 \mathrm{~cm}$-thick and $3 \mathrm{~cm}$-thick steaks were cooked at $170^{\circ} \mathrm{C}$ or $230^{\circ} \mathrm{C}$, to $63^{\circ} \mathrm{C}$. These steaks too were turned over twice during cooking, at intervals of 6 and 5 min for $2.0 \mathrm{~cm}$-thick steaks cooked at $170^{\circ} \mathrm{C}$ or $230^{\circ} \mathrm{C}$, respectively; and at intervals of $10 \mathrm{~min}$ for $3 \mathrm{~cm}$-thick steaks cooked at either temperature. In addition, 2 groups of $2 \mathrm{~cm}$-thick steaks and 2 groups of 3 -cm thick were cooked at $200^{\circ} \mathrm{C}$, to $63^{\circ} \mathrm{C}$, and were turned over every $2 \mathrm{~min}$ or 4 min during cooking of the $2 \mathrm{~cm}$-thick and $3 \mathrm{~cm}$-thick steaks, respectively.

\subsection{Analysis of Data}

Mean values for sets of times at which steaks were turned over, times for which steaks were cooked, temperatures at points in steaks when they were cooked, temperatures at points in steaks when they were turned over or maximum temperatures attained at points in steaks were separated using the Tukey option of the GLM procedures in SAS, version 12 (SAS Institute, Cary, NC, USA). Each temperature history obtained from a steak during cooking was integrated with respect to models for the thermal inactivation of E. coli, E. coli $\mathrm{O} 157: \mathrm{H} 7$ and Salmonella. The model for E. coli is a global model derived from data from multiple sources (Van Asselt \& Zwietering, 2006). The model for E. coli $\mathrm{O} 157: \mathrm{H} 7$ was derived from data for thermal inactivation of the organism in ground beef (Weigand et al., 2012). The model for Salmonella was derived from data for inactivation of the organism in ground beef (Goodfellow \& Brown, 1978). These data are used by US regulatory authorities for determination ofmeat cooking treatments that are adequate for inactivation of Salmonella and $E$. coli O157:H7 (USDA/FSIS, 2009). All models were of the form $\log \mathrm{D}=\log \mathrm{D}_{\text {ref }}-\left(\mathrm{T}-\mathrm{T}_{\text {ref }}\right) / \mathrm{z}$, where $\mathrm{D}$ is the time required for a $1 \log$ reduction in numbers of viable bacteria at a specified lethal temperature, $\mathrm{z}$ is the difference in lethal temperatures for which there is a 10 -fold different in $\mathrm{D}$-values, $\mathrm{T}$ is the temperature to which the organism is exposed, and $D_{\text {ref }}$ is the $D$-value at the reference temperature $T_{\text {ref. }}$. The value for $T_{\text {ref }}, D_{\text {ref }}$ and $z$ used for the models were: for E. coli, $\mathrm{T}_{\text {ref }}=70^{\circ} \mathrm{C}, \mathrm{D}_{\text {ref }}=12.8 \mathrm{~s}, \mathrm{z}=10.6^{\circ} \mathrm{C}$; for $E$. coli O157: $\mathrm{H} 7, \mathrm{~T}_{\text {ref }}=60^{\circ} \mathrm{C}, \mathrm{D}_{\text {ref }}$ $=109 \mathrm{~s}, \mathrm{z}=5.06^{\circ} \mathrm{C}$; for Salmonella, $\mathrm{D}_{\text {ref }}=60^{\circ} \mathrm{C}, \mathrm{D}_{60}=108 \mathrm{~s}, \mathrm{z}=5.71^{\circ} \mathrm{C}$. The log reduction in the numbers of each organism experiencing each temperature history was calculated by calculating the incremental reduction during $10 \mathrm{~s}$ at each recorded temperature and summing the log reduction values.

All values for the numbers of $E$. coli $\mathrm{O} 157: \mathrm{H} 7$ recovered from inoculated sites in steaks were converted to log values and reported as such.

\section{Results}

\subsection{Steaks $3 \mathrm{~cm}$-Thick, Turned over at $30^{\circ} \mathrm{C}$ or $50^{\circ} \mathrm{C}$ and Cooked to Various Temperatures}

The mean temperature at the centres of the steaks when cooking commenced was $3.9^{\circ} \mathrm{C}$, with the temperatures ranging from 3.0 to $6.2^{\circ} \mathrm{C}$. The mean times for the centres of steaks to reach $30^{\circ} \mathrm{C}$ or $50^{\circ} \mathrm{C}$ were $10.5 \mathrm{~min}$ and $18.0 \mathrm{~min}$, respectively (Table 1). However, the times taken for the centres of individual steaks to reach either temperature varied from the mean value by up to $\pm 5 \mathrm{~min}$. The mean time to reach a specified temperature at the centre after steaks were turned over when the temperature at the centre was $30^{\circ} \mathrm{C}$ was generally less than the mean time taken to reach the same temperature at the centres of steaks turned over when the temperature at the centre was $50^{\circ} \mathrm{C}$. Among steaks turned over at either temperature, the time to reach the specified temperature generally increased as the specified temperature increased. However, within any group of 5 steaks the time taken 
to reach the specified temperature at the centre varied by $\geq 5 \mathrm{~min}$.

Table 1. Times to turning over once at 30 or $50^{\circ} \mathrm{C}$ and for cooking groups of $53 \mathrm{~cm}$-thick steaks to various temperatures at the centre

\begin{tabular}{|c|c|c|c|c|c|}
\hline \multicolumn{2}{|c|}{ Temperatures $\left({ }^{\circ} \mathrm{C}\right)$} & \multicolumn{4}{|c|}{ Time (min) } \\
\hline \multirow{2}{*}{ At turning over } & \multirow{2}{*}{ At end of cooking } & \multicolumn{2}{|c|}{ At turning over } & \multicolumn{2}{|c|}{ At the end of cooking } \\
\hline & & Mean & Range & Mean & Range \\
\hline \multirow[t]{4}{*}{30} & 60 & $9.8^{\mathrm{A}}$ & 6-14 & $21.6^{\mathrm{AB}}$ & $19-26$ \\
\hline & 65 & $11.2^{\mathrm{AB}}$ & $9-12$ & $20.6^{\mathrm{B}}$ & $18-26$ \\
\hline & 70 & $9.2^{\mathrm{A}}$ & $7-13$ & $28.2^{\mathrm{AB}}$ & $20-44$ \\
\hline & 75 & $11.6^{\mathrm{AB}}$ & $8-15$ & $25.2^{\mathrm{AB}}$ & $23-31$ \\
\hline \multirow[t]{4}{*}{50} & 60 & $19.0^{\mathrm{C}}$ & $14-23$ & $27.0^{\mathrm{AB}}$ & $20-36$ \\
\hline & 65 & $18.4^{\mathrm{C}}$ & $13-22$ & $26.0^{\mathrm{AB}}$ & $22-32$ \\
\hline & 70 & $17.4^{\mathrm{BC}}$ & $13-20$ & $25.4^{\mathrm{AB}}$ & $23-28$ \\
\hline & 75 & $17.0^{\mathrm{C}}$ & $13-19$ & $32.2^{\mathrm{AB}}$ & $27-40$ \\
\hline
\end{tabular}

Mean values in the same column with the same letter are not significantly different $(\mathrm{P}>0.05)$.

During holding for $5 \mathrm{~min}$ after cooking ended, the maximum temperatures attained at the centres of steaks were generally $\leq 2^{\circ} \mathrm{C}$ more than the temperature when cooking was ended (Table 2). With many steaks there was no increase in temperature at the centre after cooking ended. In all groups of 5 steaks the maximum temperatures attained in some steaks at points $1 \mathrm{~cm}$ from the side, $2 \mathrm{~cm}$ from the side, and/or $1 \mathrm{~cm}$ from the upper surface after turning over were less than the temperatures attained at the steak centres. In contrast, with few exceptions the maximum temperatures attained at points $2 \mathrm{~cm}$ below the upper surfaces after steaks were turned over were higher than the temperatures attained at the centres.

Table 2. Means and ranges for the maximum temperatures attained at 5 points in steaks that were turned over once at 30 or $50^{\circ} \mathrm{C}$, cooked to various temperatures at the centre, and held for 5 min after cooking ended

\begin{tabular}{|c|c|c|c|c|c|c|c|c|c|c|c|}
\hline \multicolumn{2}{|c|}{ Temp. $\left({ }^{\circ} \mathrm{C}\right)$} & \multicolumn{10}{|c|}{ Maximum temperatures $\left({ }^{\circ} \mathrm{C}\right)$} \\
\hline \multirow{3}{*}{$\begin{array}{l}\text { At } \\
\text { the } \\
\text { turn }\end{array}$} & \multirow{3}{*}{$\begin{array}{l}\text { At } \\
\text { the } \\
\text { end }\end{array}$} & \multirow{2}{*}{\multicolumn{2}{|c|}{ Centre }} & \multicolumn{4}{|c|}{ Distance from side ${ }^{\mathrm{a}}$} & \multicolumn{4}{|c|}{ Distance from upper surface ${ }^{\mathrm{b}}$} \\
\hline & & & & \multicolumn{2}{|c|}{$1 \mathrm{~cm}$} & \multicolumn{2}{|c|}{$2 \mathrm{~cm}$} & \multicolumn{2}{|c|}{$1 \mathrm{~cm}$} & \multicolumn{2}{|c|}{$2 \mathrm{~cm}$} \\
\hline & & Mean & Range & Mean & Range & Mean & Range & Mean & Range & Mean & range \\
\hline \multirow[t]{4}{*}{30} & 60 & $62.0^{\mathrm{A}}$ & 62 & $62.6^{\mathrm{A}}$ & $56-72$ & $64.8^{\mathrm{A}}$ & $55-82$ & $57.0^{\mathrm{A}}$ & $54-60$ & $68.6^{\mathrm{AB}}$ & $64-72$ \\
\hline & 65 & $65.8^{\mathrm{B}}$ & $65-66$ & $65.2^{\mathrm{A}}$ & $57-70$ & $67.2^{\mathrm{A}}$ & $61-85$ & $58.0^{\mathrm{AB}}$ & $55-63$ & $70.6^{\mathrm{ABC}}$ & $62-76$ \\
\hline & 70 & $70.6^{\mathrm{C}}$ & $70-72$ & $66.2^{\mathrm{A}}$ & $56-78$ & $70.8^{\mathrm{A}}$ & $63-77$ & $62.4^{\mathrm{CD}}$ & $58-67$ & $77.2^{\mathrm{ACD}}$ & $72-79$ \\
\hline & 75 & $75.4^{\mathrm{D}}$ & $75-77$ & $64.4^{\mathrm{A}}$ & $54-71$ & $69.0^{\mathrm{A}}$ & 54.77 & $61.4^{\mathrm{BC}}$ & $57-64$ & $79.4^{\mathrm{ACD}}$ & $74-84$ \\
\hline \multirow[t]{4}{*}{50} & 60 & $62.4^{\mathrm{A}}$ & $60-65$ & $66.2^{\mathrm{A}}$ & $58-75$ & $63.2^{\mathrm{A}}$ & $59-68$ & $69.0^{\mathrm{D}}$ & $65-74$ & $68.2^{\mathrm{A}}$ & $65-73$ \\
\hline & 65 & $65.2^{\mathrm{B}}$ & $65-66$ & $68.0^{\mathrm{A}}$ & $64-74$ & $68.2^{\mathrm{A}}$ & $62-74$ & $66.4^{\mathrm{CD}}$ & $62-72$ & $77.4^{\mathrm{BCD}}$ & $73-84$ \\
\hline & 70 & $70.2^{\mathrm{C}}$ & $70-71$ & $71.6^{\mathrm{A}}$ & $68-75$ & $66.4^{\mathrm{A}}$ & 63-69 & $66.4^{\mathrm{CD}}$ & $62-70$ & $80.0^{\mathrm{D}}$ & $76-88$ \\
\hline & 75 & $75.0^{\mathrm{D}}$ & 75 & $70.2^{\mathrm{A}}$ & $65-78$ & $73.2^{\mathrm{A}}$ & $65-81$ & $64.6^{\mathrm{CD}}$ & $63-66$ & $82.2^{\mathrm{D}}$ & $80-89$ \\
\hline
\end{tabular}

${ }^{\mathrm{a}}$ Temperature recording started when cooking began.

${ }^{\mathrm{b}}$ Temperature recording started after steaks had been turned over.

Mean values in the same column with the same letter are not significantly different $(\mathrm{P}>0.05)$. 
Values for reductions in the numbers of $E$. coli $\mathrm{O} 157: \mathrm{H} 7$ calculated for temperature histories until the end of cooking were $>5 \log$ cfu for some points in some steaks in all groups of steaks turned over when the temperature at the centre reached $30^{\circ} \mathrm{C}$ (Table 3). The values calculated for reductions in E. coli $\mathrm{O} 157: \mathrm{H} 7$ numbers for 5 histories of temperatures until the end of cooking for points at the centres of steaks cooked to $60^{\circ} \mathrm{C}$ or $65^{\circ} \mathrm{C}$ were $<5 \log$ cfu. Values calculated for 4 of those temperature histories extended for 5 min after the end of cooking were $>5 \log \mathrm{cfu}$. For temperature histories from other points in steaks, when values for reductions in the numbers of $E$. coli $\mathrm{O} 157: \mathrm{H} 7$ calculated for times until the end of cooking were $<5 \log \mathrm{cfu}$, the values calculated for times 5 min after the end of cooking were also $<5 \log$ cfu. For steaks that were turned over when the temperatures at the centres reached $50^{\circ} \mathrm{C}$, only steaks cooked to $60^{\circ} \mathrm{C}$ gave temperature histories until 5 min after cooking for which values for E. coli O157:H7 reductions were $<5 \log$ cfu. Values $<5 \log$ cfu were calculated for only one temperature history from points $2 \mathrm{~cm}$ below the upper surfaces after steaks had been turned over.

Table 3. Numbers of values $<5 \log$ cfu in groups of 5 values for decreases in the numbers of Escherichia coli O157:H7 calculated from temperature histories collected from 5 points in $3 \mathrm{~cm}$-thick steaks that were turned over once at 30 or $50^{\circ} \mathrm{C}$, cooked to various temperatures at the centre, and held for $5 \mathrm{~min}$ after cooking ended

\begin{tabular}{|c|c|c|c|c|c|c|c|c|c|c|c|}
\hline \multicolumn{2}{|c|}{$\begin{array}{c}\text { Cooking temperatures } \\
\left({ }^{\circ} \mathrm{C}\right) \\
\end{array}$} & \multicolumn{10}{|c|}{ Number of values $<5 \log$ cfu } \\
\hline \multirow{3}{*}{$\begin{array}{c}\text { At turning } \\
\text { over }\end{array}$} & \multirow{3}{*}{$\begin{array}{l}\text { At end of } \\
\text { cooking }\end{array}$} & \multicolumn{5}{|c|}{ At the end of cooking } & \multicolumn{5}{|c|}{5 min after the end of cooking } \\
\hline & & \multirow[t]{2}{*}{ Centre $^{a}$} & \multicolumn{2}{|c|}{$\begin{array}{l}\text { Distance } \\
\text { from side }\end{array}$} & \multicolumn{2}{|c|}{$\begin{array}{l}\text { Distance from } \\
\text { upper surface }^{\mathrm{b}}\end{array}$} & \multirow[t]{2}{*}{ Centre } & \multicolumn{2}{|c|}{$\begin{array}{l}\text { Distance } \\
\text { from side }\end{array}$} & \multicolumn{2}{|c|}{$\begin{array}{l}\text { Distance from } \\
\text { upper surface }\end{array}$} \\
\hline & & & $1 \mathrm{~cm}$ & $2 \mathrm{~cm}$ & $1 \mathrm{~cm}$ & $2 \mathrm{~cm}$ & & $1 \mathrm{~cm}$ & $2 \mathrm{~cm}$ & $1 \mathrm{~cm}$ & $2 \mathrm{~cm}$ \\
\hline \multirow[t]{4}{*}{30} & 60 & 4 & 3 & 2 & 5 & $--^{c}$ & 1 & 3 & 2 & 5 & -- \\
\hline & 65 & 1 & 1 & 1 & 5 & 1 & -- & 1 & 1 & 5 & 1 \\
\hline & 70 & -- & 1 & -- & 3 & -- & -- & 1 & -- & 3 & -- \\
\hline & 75 & -- & 1 & 1 & 1 & -- & -- & 1 & 1 & 1 & -- \\
\hline \multirow[t]{4}{*}{50} & 60 & 2 & 1 & 2 & 2 & -- & 1 & 1 & 1 & 2 & -- \\
\hline & 65 & -- & 1 & 1 & 1 & -- & -- & -- & -- & -- & -- \\
\hline & 70 & -- & -- & -- & 1 & -- & -- & -- & -- & -- & -- \\
\hline & 75 & -- & -- & -- & -- & -- & -- & -- & -- & -- & -- \\
\hline
\end{tabular}

${ }^{a}$ Temperature recording started when cooking began.

${ }^{\mathrm{b}}$ Temperature recording started after steaks had been turned over.

${ }^{\mathrm{c}}$ Value is $\geq 5 \log \mathrm{cfu}$.

\subsection{Steaks Inoculated with E. coli O157:H7, Turned Over Once at $50^{\circ} \mathrm{C}$ and Cooked to 60,63 or $65^{\circ} \mathrm{C}$}

The times of cooking $3 \mathrm{~cm}$-thick steaks to a temperature at the centre of $50^{\circ} \mathrm{C}$ before turning over, and the times for cooking to the specified temperatures were similar to the corresponding times found previously for turning over and cooking the $3 \mathrm{~cm}$-thick steaks that were not inoculated (Table 4). The times for turning over $2 \mathrm{~cm}$-thick steaks at $50^{\circ} \mathrm{C}$ and cooking those steaks to the specified temperatures were about $65 \%$ of the times for turning over or cooking $3 \mathrm{~cm}$-thick steaks. The maximum temperatures attained at points $1 \mathrm{~cm}$ from the sides of steaks or from points initially below the central planes of steaks were mostly higher than the temperatures at the centres of steaks when cooking ended.

The numbers of E. coli $\mathrm{O} 157: \mathrm{H} 7$ recovered from inoculated steaks that were not cooked ranged from 4.85 to $6.39 \log$ cfu/inoculated site. Only 2 of the 18 inoculated sites yielded the organisms at numbers $<5 \log \mathrm{cfu}$. It was then assumed that all inoculated sites in the steaks initially contained E. coli O157:H7 at numbers approximating or exceeding $5 \log$ cfu. 
Table 4. Times to turning over once at $50^{\circ} \mathrm{C}$ and cooking groups of $53 \mathrm{~cm}$-thick or $2 \mathrm{~cm}$-thick steaks to 60,63 or $65^{\circ} \mathrm{C}$ at the centre, and the maximum temperatures attained at points $1 \mathrm{~cm}$ from the side and $2 \mathrm{~cm}$ or $1.5 \mathrm{~cm}$ below the surface uppermost when cooking commenced

\begin{tabular}{|c|c|c|c|c|c|c|c|c|c|}
\hline \multirow{3}{*}{$\begin{array}{c}\text { Steak } \\
\text { thickness } \\
(\mathrm{cm})\end{array}$} & \multirow{3}{*}{$\begin{array}{l}\text { Temp. at end of } \\
\text { cooking }\left({ }^{\circ} \mathrm{C}\right)\end{array}$} & \multicolumn{4}{|c|}{ Cooking time (min) } & \multicolumn{4}{|c|}{ Maximum temperature $\left({ }^{\circ} \mathrm{C}\right)$} \\
\hline & & \multicolumn{2}{|c|}{$\begin{array}{l}\text { At turning } \\
\text { over }\end{array}$} & \multicolumn{2}{|c|}{$\begin{array}{l}\text { At end of } \\
\text { cooking }\end{array}$} & \multicolumn{2}{|c|}{$\begin{array}{l}1 \mathrm{~cm} \text { from the } \\
\text { side }\end{array}$} & \multicolumn{2}{|c|}{$\begin{array}{c}2 \mathrm{~cm} \text { or } 1.5 \mathrm{~cm} \text { from } \\
\text { surface }\end{array}$} \\
\hline & & Mean & $\overline{\text { Range }}$ & Mean & Range & Mean & Range & Mean & Range \\
\hline \multirow[t]{3}{*}{3} & 60 & $19.4^{\mathrm{A}}$ & $15-25$ & $26.4^{\mathrm{A}}$ & $21-29$ & $74.0^{\mathrm{A}}$ & $71-77$ & $68.9^{\mathrm{A}}$ & $66-73$ \\
\hline & 63 & $17.2^{\mathrm{AB}}$ & $13-21$ & $29.0^{\mathrm{A}}$ & $25-32$ & $74.6^{\mathrm{A}}$ & $72-81$ & $66.2^{\mathrm{A}}$ & $62-72$ \\
\hline & 65 & $17.6^{\mathrm{AB}}$ & $10-23$ & $25.0^{\mathrm{A}}$ & $22-27$ & $72.0^{\mathrm{A}}$ & $62-76$ & $68.6^{\mathrm{A}}$ & $59-74$ \\
\hline \multirow{3}{*}{2} & 60 & $10.2^{\mathrm{C}}$ & $12-15$ & $13.2^{\mathrm{B}}$ & $12-15$ & $68.6^{\mathrm{AB}}$ & $64-75$ & $72.8^{\mathrm{A}}$ & $68-77$ \\
\hline & 63 & $12.8^{\mathrm{BC}}$ & $9-17$ & $15.8^{\mathrm{B}}$ & $12-17$ & $70.4^{\mathrm{AB}}$ & $65-75$ & $71.6^{\mathrm{A}}$ & $69-74$ \\
\hline & 65 & $12.0^{\mathrm{BC}}$ & $8-17$ & $14.8^{\mathrm{B}}$ & $12-18$ & $62.4^{\mathrm{B}}$ & $60-69$ & $69.8^{\mathrm{A}}$ & $68-71$ \\
\hline
\end{tabular}

${ }^{a}$ Temperatures were recorded from $2 \mathrm{~cm}$ below or $1.5 \mathrm{~cm}$ below the initially upper surfaces of $3 \mathrm{~cm}$-thick and 2 $\mathrm{cm}$-thick steaks, respectively; temperature histories were collected from each point both before and after turning.

Mean values in the same column with the same letter are not significantly different $(\mathrm{P}>0.05)$.

E. coli $\mathrm{O} 157: \mathrm{H} 7$ were recovered from the centre of only one cooked steak (Table 5). Most groups of steaks included one or more steaks from which E. coli $\mathrm{O} 157: \mathrm{H} 7$ were recovered from the inoculated site $1 \mathrm{~cm}$ from the steak edge. Two groups of steaks included one or two steaks from which E. coli $\mathrm{O} 157: \mathrm{H} 7$ were recovered from the inoculated site initially below the central plane. In all instances, the numbers of $E$. coli O157:H7 recovered were $>1.5 \log$ cfu/inoculated site.

Table 5. Numbers of values $<5 \log$ cfu in groups of 5 values for decreases in the numbers of Escherichia coli O157:H7 inoculated at the centre (C) and at points $1 \mathrm{~cm}$ from the side (S) and $2 \mathrm{~cm}$ or $1.5 \mathrm{~cm}$ below the surface uppermost when cooking commenced (B), and in groups of 5 values for decreases in the numbers of $E$. coli, E. coli $\mathrm{O} 157: \mathrm{H} 7$ and Salmonella calculated from temperature histories collected from such points, when $3 \mathrm{~cm}$-thick or $2 \mathrm{~cm}$-thick steaks were cooked from refrigeration temperatures to $50^{\circ} \mathrm{C}$ at the centre, then turned over and cooked to 60,63 or $65^{\circ} \mathrm{C}$

\begin{tabular}{|c|c|c|c|c|c|c|c|c|c|c|c|c|c|}
\hline \multirow{4}{*}{$\begin{array}{c}\text { Steak } \\
\text { thickness-(cm) }\end{array}$} & \multirow{4}{*}{$\begin{array}{l}\text { Temp. at } \\
\text { the end of } \\
\text { cooking } \\
\left({ }^{\circ} \mathrm{C}\right)\end{array}$} & \multicolumn{12}{|c|}{ Numbers of values $<5 \log$ cfu } \\
\hline & & \multicolumn{6}{|c|}{ Inoculated } & \multicolumn{6}{|c|}{ Calculated values } \\
\hline & & \multicolumn{3}{|c|}{ E. coli $\mathrm{O} 157$} & \multicolumn{3}{|c|}{ E. coli } & \multicolumn{3}{|c|}{ E. coli $\mathrm{O} 157: \mathrm{H} 7$} & \multicolumn{3}{|c|}{ E. coli } \\
\hline & & $\mathrm{C}$ & $\mathrm{S}$ & $\mathrm{B}^{\mathrm{a}}$ & $\mathrm{C}$ & $\mathrm{S}$ & $\mathrm{B}^{\mathrm{a}}$ & $\mathrm{C}$ & $\mathrm{S}$ & $\mathrm{B}^{\mathrm{a}}$ & $\mathrm{C}$ & $\mathrm{S}$ & $\mathrm{B}^{\mathrm{a}}$ \\
\hline \multirow[t]{3}{*}{3} & 60 & $--^{b}$ & 2 & -- & 5 & 1 & 3 & 5 & -- & -- & 5 & -- & -- \\
\hline & 63 & -- & 1 & -- & 4 & -- & 4 & 4 & -- & 2 & 4 & -- & 2 \\
\hline & 65 & -- & 1 & 2 & 5 & 1 & 1 & 4 & 1 & 1 & 3 & 1 & 1 \\
\hline \multirow[t]{3}{*}{2} & 60 & 1 & 3 & 1 & 5 & 5 & 4 & 5 & 4 & 1 & 5 & 4 & 1 \\
\hline & 63 & -- & -- & -- & 5 & 2 & 2 & 5 & 1 & -- & 5 & 1 & -- \\
\hline & 65 & -- & 2 & -- & 5 & 3 & 1 & 5 & 2 & -- & 5 & 1 & -- \\
\hline
\end{tabular}

${ }^{a}$ The points that were inoculated or from which temperatures were recorded were $2 \mathrm{~cm}$ or $1.5 \mathrm{~cm}$ below the initially upper surfaces of $3 \mathrm{~cm}$-thick and $2 \mathrm{~cm}$-thick steaks, respectively.

${ }^{\mathrm{b}}$ Value is $\geq 5 \log$ cfu.

In contrast to the findings for inoculated $E$. coli $\mathrm{O} 157: \mathrm{H} 7$, the reductions in the numbers of bacteria calculated from temperature histories from points at the centres of steaks were mostly $<5 \log$ cfu (Table 5 ). Also unlike the 
findings for inoculated steaks, more reductions $<5 \log$ cfu were calculated for points initially below the central planes of $3 \mathrm{~cm}$-thick steaks than for points $1 \mathrm{~cm}$ from the edges of those steaks. With $2 \mathrm{~cm}$-thick steaks the findings with respect to reductions of inoculated E. coli $\mathrm{O} 157: \mathrm{H} 7$ and calculated reductions of $E$. coli $\mathrm{O} 157: \mathrm{H} 7$ and Salmonella at points other than at the centre were similar.

\subsection{Steaks Inoculated with E. coli O157:H7 Turned Over Once After Various Times During Cooking to $71^{\circ} \mathrm{C}$}

When $2 \mathrm{~cm}$-thick steaks were turned over once, at various times during cooking to $71^{\circ} \mathrm{C}$, the temperatures at the centres when steaks were turned over, the maximum temperatures attained at points $1 \mathrm{~cm}$ from the edges of steaks, and the time to cook to $71{ }^{\circ} \mathrm{C}$ at the centre generally increased with increasing time before steaks were turned over (Table 6). The final temperatures at points $0.5 \mathrm{~cm}$ from the edges of steaks were similar with all times of turning.

Table 6. Means and ranges for temperatures at the centres of groups of $52 \mathrm{~cm}$-thick steaks turned over once at various times during cooking to $71^{\circ} \mathrm{C}$. For the maximum temperatures attained $1 \mathrm{~cm}$ from steak edges, and for the temperature $0.5 \mathrm{~cm}$ from steak edges when cooking ended; and for the times to reach $71^{\circ} \mathrm{C}$

\begin{tabular}{|c|c|c|c|c|c|c|c|c|}
\hline \multirow[t]{2}{*}{$\begin{array}{l}\text { Time at } \\
\text { turning (min) }\end{array}$} & \multicolumn{2}{|c|}{$\begin{array}{c}\text { Temp. at } \\
\text { turning } \\
\left({ }^{\circ} \mathrm{C}\right)\end{array}$} & \multicolumn{2}{|c|}{$\begin{array}{l}\text { Maximum temp. } \\
1 \mathrm{~cm} \text { from edge }{ }^{\mathrm{a}} \\
\left({ }^{\circ} \mathrm{C}\right)\end{array}$} & \multicolumn{2}{|c|}{$\begin{array}{c}\text { Final temp. } 0.5 \mathrm{~cm} \text { from } \\
\text { edge }\left({ }^{\circ} \mathrm{C}\right)\end{array}$} & \multicolumn{2}{|c|}{$\begin{array}{l}\text { Time cooking ended } \\
\text { (min) }\end{array}$} \\
\hline & Mean & Range & Mean & Range & Mean & Range & Mean & Range \\
\hline 4 & $19.6^{\mathrm{A}}$ & $17-28$ & $69.4^{\mathrm{A}}$ & 58.75 & $67.9^{\mathrm{A}}$ & $58-77$ & $12.4^{\mathrm{A}}$ & 9-14 \\
\hline 6 & $24.0^{\mathrm{A}}$ & $19-32$ & $67.6^{\mathrm{A}}$ & $56-75$ & $65.1^{\mathrm{A}}$ & $51-80$ & $13.2^{\mathrm{A}}$ & $12-16$ \\
\hline 8 & $38.0^{\mathrm{B}}$ & $26-45$ & $74.0^{\mathrm{B}}$ & $69-81$ & $66.2^{\mathrm{AB}}$ & $60-74$ & $15.4^{\mathrm{A}}$ & $12-17$ \\
\hline 10 & $56.6^{\mathrm{C}}$ & $52-63$ & $76.2^{\mathrm{B}}$ & $72-81$ & $70.8^{\mathrm{BC}}$ & $65-80$ & $17.6^{\mathrm{AB}}$ & $14-23$ \\
\hline 12 & $62.4^{\mathrm{C}}$ & 55-69 & $78.0^{\mathrm{B}}$ & 69-87 & $70.6^{\mathrm{BC}}$ & $66-75$ & $23.6^{\mathrm{B}}$ & $17-29$ \\
\hline 14 & $62.2^{\mathrm{C}}$ & $57-68$ & $78.6^{\mathrm{B}}$ & $78-82$ & $73.0^{\mathrm{C}}$ & $66-78$ & $22.4^{\mathrm{B}}$ & $20-25$ \\
\hline
\end{tabular}

${ }^{a}$ Maximum temperature recorded in the temperature history for the whole time of cooking.

Mean values in the same column with the same letter are not significantly different $(\mathrm{P}>0.05)$.

Table 7. Ranges of the numbers of Escherichia coli O157:H7 (log cfu) recovered from the centres, and $1.0 \mathrm{~cm}$ and $0.5 \mathrm{~cm}$ from the edges of single $2 \mathrm{~cm}$-thick raw inoculated steaks and the numbers of positive samples and ranges of the numbers recovered from those points in groups of 5 inoculated steaks that were turned once at different times during cooking from refrigerator temperatures to $71^{\circ} \mathrm{C}$

\begin{tabular}{|c|c|c|c|c|c|c|c|}
\hline \multirow{4}{*}{$\begin{array}{c}\text { Time of } \\
\text { turning (min) }\end{array}$} & \multicolumn{7}{|c|}{ E. coli $\mathrm{O} 157: \mathrm{H} 7$} \\
\hline & \multirow{3}{*}{$\begin{array}{c}\text { Range in } \\
\text { raw steaks (log cfu) }\end{array}$} & \multicolumn{3}{|c|}{ Number of positive samples } & \multicolumn{3}{|c|}{ Range in positive samples (log cfu) } \\
\hline & & \multirow{2}{*}{ Centre } & \multicolumn{2}{|c|}{ Distance from edge } & \multirow{2}{*}{ Centre } & \multicolumn{2}{|c|}{ Distance from edge } \\
\hline & & & $1.0 \mathrm{~cm}$ & $0.5 \mathrm{~cm}$ & & $1.0 \mathrm{~cm}$ & $0.5 \mathrm{~cm}$ \\
\hline 4 & $5.57-5.91$ & 4 & 5 & 5 & $2.45->5.0$ & $0.78-2.74$ & $0.60-3.46$ \\
\hline 6 & $5.57-5.91$ & 3 & 1 & 2 & $1.59-2.48$ & 2.87 & $1.08-1.81$ \\
\hline 8 & $5.98-6.01$ & 2 & 2 & $5^{\mathrm{a}}$ & $2.57-3.20$ & $0.30-3.13$ & $0.00-3.77$ \\
\hline 10 & $5.15-5.99$ & 0 & 0 & 0 & $\mathrm{ND}^{\mathrm{b}}$ & ND & ND \\
\hline 12 & $5.87-6.03$ & 0 & 0 & 0 & ND & ND & ND \\
\hline 14 & $5.54-5.97$ & 0 & 0 & 0 & ND & ND & ND \\
\hline
\end{tabular}

${ }^{\mathrm{a}}$ Two values $\leq 0.30 \log$ cfu.

${ }^{\mathrm{b}} \mathrm{ND}$, none detected.

The number of $E$. coli $\mathrm{O} 157: \mathrm{H} 7$ recovered from each inoculated point in raw steaks was $>5$ log cfu (Table 7). $E$. coli $\mathrm{O} 157: \mathrm{H} 7$ were recovered from $\geq 6$ samples from each group of steaks turned over after cooking for $\leq 8$ min. 
No E. coli $\mathrm{O} 157: \mathrm{H} 7$ were recovered from steaks turned over after cooking for $\geq 10 \mathrm{~min}$. The temperatures at steak centres when steaks were turned over after cooking for $\geq 10$ min were $>50^{\circ} \mathrm{C}$ (Table 6).

\subsection{Steaks Inoculated With E. coli O157:H7 Turned Over More Than Once During Cooking to $63^{\circ} \mathrm{C}$}

Two groups of $3 \mathrm{~cm}$-thick steaks and two groups of $2 \mathrm{~cm}$-thick steaks were inoculated with $>5 \log \mathrm{cfu}$ of $E$. coli O157:H7 at their centres and $1 \mathrm{~cm}$ from their edges. When the $3 \mathrm{~cm}$-thick and 2-cm thick steaks were turned at intervals of $4 \mathrm{~min}$ and $2 \mathrm{~min}$, respectively, during cooking to $63^{\circ} \mathrm{C}$, no E. coli $\mathrm{O} 157: \mathrm{H} 7$ were recovered from the cooked steaks (data not presented).

Groups of steaks of thicknesses between $1.0 \mathrm{~cm}$ and $3.0 \mathrm{~cm}$, inclusive, were inoculated with E. coli $\mathrm{O} 157: \mathrm{H} 7$ at their centres and at points $1.0 \mathrm{~cm}$ and $0.5 \mathrm{~cm}$ from their edges. The steaks were turned twice at intervals related to the expected cooking times, during cooking to $63^{\circ} \mathrm{C}$ on a hot plate operating at $200^{\circ} \mathrm{C}$. No E. coli $\mathrm{O} 157: \mathrm{H} 7$ were recovered from the cooked steaks (Table 8). Similarly inoculated groups of $2 \mathrm{~cm}$-thick and $3 \mathrm{~cm}$-thick were cooked in the same manner on a hot plate operating at $170^{\circ} \mathrm{C}$ or $230^{\circ} \mathrm{C}$. Again, no E. coli $\mathrm{O} 157: \mathrm{H} 7$ were recovered from the cooked steaks (data not presented).

Table 8. Intervals at which groups of 5 steaks of various thicknesses inoculated with Escherichia coli O157:H7, at their centre and $1.0 \mathrm{~cm}$ and $0.5 \mathrm{~cm}$ from their edges, had been turned over twice during cooking to $63^{\circ} \mathrm{C}$, when no $E$. coli $\mathrm{O} 157: \mathrm{H} 7$ were recovered

\begin{tabular}{|c|c|c|c|c|c|}
\hline \multirow{2}{*}{$\begin{array}{l}\text { Hot plate } \\
\text { temperature } \\
\left({ }^{\circ} \mathrm{C}\right)\end{array}$} & \multirow{2}{*}{$\begin{array}{c}\text { Steak thickness } \\
\left({ }^{\circ} \mathrm{C}\right)\end{array}$} & \multirow{2}{*}{$\begin{array}{l}\text { Inoculum (log } \\
\text { cfu) }\end{array}$} & \multirow{2}{*}{$\begin{array}{c}\text { Turning } \\
\text { Interval } \\
\text { (min) }\end{array}$} & \multicolumn{2}{|c|}{ Cooking time (min) } \\
\hline & & & & Mean & Range \\
\hline \multirow[t]{5}{*}{200} & 1.0 & $4.48-5.92$ & 2 & $4.8^{\mathrm{A}}$ & $4-5$ \\
\hline & 1.5 & $5.72-6.15$ & 4 & $9.2^{\mathrm{B}}$ & $8-11$ \\
\hline & 2.0 & $5.90-6.02$ & 6 & $13.0^{\mathrm{C}}$ & $12-14$ \\
\hline & 2.5 & $6.21-6.27$ & 8 & $21.0^{\mathrm{D}}$ & $19-26$ \\
\hline & 3.0 & $6.31-6.51$ & 10 & $24.4^{\mathrm{E}}$ & $23-25$ \\
\hline \multirow[t]{2}{*}{170} & 2.0 & $5.69-6.16$ & 6 & $14.6^{\mathrm{C}}$ & $13-17$ \\
\hline & 3.0 & $5.97-6.39$ & 10 & $27.4^{\mathrm{E}}$ & $24-33$ \\
\hline \multirow[t]{2}{*}{230} & 2.0 & $5.83-6.39$ & 5 & $11.8^{\mathrm{BC}}$ & $11-14$ \\
\hline & 3.0 & $5.68-6.07$ & 10 & $26.2^{\mathrm{E}}$ & $24-29$ \\
\hline
\end{tabular}

Mean values in the same column with the same letter are not significantly different $(\mathrm{P}>0.05)$.

\section{Discussion}

The initial collection of temperature histories from various points in $3 \mathrm{~cm}$-thick steaks was carried out to ascertain if some points in grilled steaks that were turned over only once during cooking might experience temperatures that would be less lethal for E. coli $0157: \mathrm{H} 7$ than temperatures at steak centres. Steaks 3 $\mathrm{cm}$-thickwere used to ensure temperature histories were sufficiently long for ready discrimination of differences between them. Although most culinary instructions recommend that steaks be grilled from room temperature, steaks in this study were cooked from refrigerator temperatures. This was because holding raw beef at room temperature must be regarded as an unsafe practice (BIC, 2009). Moreover, it is apparently usual restaurant practice, and probably common practice in cooking at home to keep steaks under refrigeration until they are grilled (Raichlen, 2010). Instructions for cooking raw meats generally specify a minimum temperature to be attained at the centres of cooked items. The assumption underlying such recommendations is that all other points in an item will experience heating that is equally or more lethal for pathogens than the heating at the centre. In agreement with this, a recent study of grilling of simulated steaks found that temperatures at points $0.5 \mathrm{~cm}$ from the edges or below the surfaces of the steaks rose more rapidly to equal or higher temperature than temperatures 
at steak centres (Shen, Geornaras, Belk, Smith, \& Sofos, 2011). In contrast,with some of the $3 \mathrm{~cm}$-thick steaks cooked in our study, temperature at points close to the sides or above the central plane after steaks were turned over did not reach the temperatures attained at the centres. The values for reductions in E. coli O157:H7 numbers calculated from temperature histories indicated that holding steaks after cooking ended would substantially enhance inactivation of $E$. coli $\mathrm{O} 157: \mathrm{H} 7$ at steak centres, and at other points in steaks that were cooked to $50^{\circ} \mathrm{C}$ at the centre before they were turned over. However, inactivation of E. coli $\mathrm{O} 157: \mathrm{H} 7$ at points other than the centre in steaks turned over when the temperature at their centres was $30^{\circ} \mathrm{C}$ apparently was not greatly enhanced by holding after cooking ended.

On the basis of those findings, further work was conducted with steaks that were each inoculated at the centre and at two other points that, in some instances, would likely not reach the temperatures attained at the centre. The steaks were cooked to temperatures that would give meat of less than well done conditions, but that might be adequate for inactivating E. coli $\mathrm{O} 157: \mathrm{H} 7$ provided the steaks were turned over when the temperature at the centre reached $50^{\circ} \mathrm{C}$. Steaks $2 \mathrm{~cm}$-thick as well as $3 \mathrm{~cm}$-thick were used because the usual thickness of steaks on retail sale in North America is now apparently about $2 \mathrm{~cm}$ (Juarez, Klassen, Larsen, \& Aalhus, 2012). The findings indicated that $E$. coli $\mathrm{O} 157: \mathrm{H7}$ inoculated into steaks were more likely to survive at points close to the edge than at other points in steaks cooked by grilling. This has particular significance for steaks cut from mechanically tenderized primals, because the bacteria in tenderized tissues are most numerous in the region immediately below the incised surface (Gill \& McGinnis, 2005; Luchansky, Phebus, Thippareddi, \& Call, 2008). The incised surface will, of course, be one edge of a steak cut from a tenderized primal.

The values calculated from temperature histories for reductions in the numbers of E. coli O157:H7, E. coli or Salmonella were generally substantially less than the reductions $<5 \log$ cfu in the numbers of E. coli O157:H7 inoculated at corresponding sites. In contrast, in several other studies the reductions in the numbers of Salmonella in preparations of whole muscle incubated at constant temperatures were found to be consistently lower than reductions estimated from models based on data for thermal inactivation of the organism in ground meat (Mongollon, Marks, Booren, Orta-Ramirez, \& Ryser, 2009; Velasquez et al., 2010). Similarly, reduction in numbers of E. coli $\mathrm{O} 157: \mathrm{H} 7$ inoculated into beef roasts were, at late times during cooking, less than values for reductions estimated from models for thermal inactivation of the organism in ground beef and temperature histories from the cooking roasts (Wiegand et al., 2012). However, at early cooking times the estimated reductions were less than those found for the inoculated organisms. The findings for steaks cooked to relatively low temperatures in ourstudy would then seem to be compatible with those latter observations.

The initial findings of this study indicated that if steaks are turned over only once during cooking, turning them over too soon may result in some parts of the steak experiencing temperatures sufficient for only relatively small reductions in numbers of $E$. coli $\mathrm{O} 157: \mathrm{H} 7$. At some points in some $2 \mathrm{~cm}$-thick steaks turned over at times $\leq 10$ min during cooking to $71^{\circ} \mathrm{C}$ reductions were about $2 \log$ units. In one instance the reduction in E. coli $\mathrm{O} 157: \mathrm{H} 7$ numbers at one point in a steak turned over after cooking for 4 min was $<1 \log$ unit. In culinary instructions for cooking $2.5 \mathrm{~cm}$-thick (i.e. 1 inch-thick) steaks the recommended times for turning steaks over once during grilling are generally $<10 \mathrm{~min}$. It therefore seems that cooking steaks to $71^{\circ} \mathrm{C}$ while following culinary recommendations about turning them over during grilling will not ensure that all parts of all steaks will experience temperatures that would be sufficient to reduce numbers of $E$. coli $\mathrm{O} 157: \mathrm{H} 7$ by several $\log$ units.

Very uneven heating of steak can evidently occur when they are turned over only once during grilling. Turning steaks more often during cooking could be expected to give more even heating (Ou \& Mittal, 2006). With more even heating, attainment of temperatures $<71^{\circ} \mathrm{C}$ at the centre might be sufficient for relatively large reductions of $E$. coli $\mathrm{O} 157: \mathrm{H} 7$ numbers at all points in steaks. That this is so indicated by the finding that $E$. coli $\mathrm{O} 157: \mathrm{H} 7$ was eliminated from inoculated steaks when they were turned frequently during cooking to $63^{\circ} \mathrm{C}$. This finding is somewhat at variance with findings in a previous study of reduction in the numbers of E. coli $\mathrm{O} 157: \mathrm{H} 7$ at the centres of some steaks turned frequently during cooking to $63^{\circ} \mathrm{C}$ being $>3<4 \log$ cfu (Gill et al., 2009). The difference might be because in the previous study steaks were inoculated with larger numbers of E. coli $\mathrm{O} 157: \mathrm{H} 7$, in a larger volume of broth, and without disruption of the inoculated tissues. The method of inoculation used in this study is possibly the better approximation to contamination by bacteria from tenderizer blades while the former method better approximates contamination with injected brine. The consistent elimination of all E. coli O157:H7 from steaks turned over twice during cooking to $63^{\circ} \mathrm{C}$ is agreeable with that possibility.

Inoculated steaks were turned over twice during cooking to $63^{\circ} \mathrm{C}$ to obtain indication of how frequently steaks might need to be turned over during cooking to ensure reductions of numbers of E. coli $\mathrm{O} 157: \mathrm{H} 7$ at all points in a steak could be large. The findings showed turning over twice was sufficient for that purpose, provided the interval between turning times was appropriate to the thickness of the steak. The findings also indicated that the 
same times of turning over would be appropriate for grilling steaks on hot surfaces at temperatures ranging from $170^{\circ} \mathrm{C}$ to $230^{\circ} \mathrm{C}$.

Only one type of steak and one method of cooking, and a limited number of cooking procedures were used in this study. There must then be uncertainty about the extent to which the findings are broadly applicable for defining conditions for grilling mechanically tenderized steak to ensure their microbiological safety. Further work on the matter is obviously required. However, the findings clearly show that, in some circumstances at least, cooking steaks to $71^{\circ} \mathrm{C}$ after turning over once could have relatively small effect on $E$. coli $\mathrm{O} 157: \mathrm{H} 7$ at some points in some steaks. The findings also show that turning steaks over more than once during grilling will give greater certainty of adequate heating of all parts of steak than will turning over only once. Moreover, temperature history data indicated that holding steaks after cooking when they are turned over only once during grilling will not reliably compensate for inadequate heating of some parts of the steaks during cooking. These factors should be taken into account in the formulation of instructions for safe cooking of mechanically tenderized steaks.

\section{Acknowledgements}

We thank Ms. J. Devos, F. Tran and S. Zawadski for technical assistance with various parts of the study; and Mr. M. Klassen for arranging funding for this study as part of the E. coli O157 Research and Education Strategy of the Canadian Cattlemen's Association. Funding for the study was provided by the Alberta Livestock and Meat Agency through the Agency's Strategic Initiatives Program.

\section{References}

Beef information Centre, BIC. (2009). Cooking and preparing beef FAQ: Canadian Beef, Calgary. Retrieved from http://www.beefinfo.org/?ID=11\&ArticleID $=55 \&$ SecID $=8$

Catford, A., Lavoie, M. C., Smith, B., Buenaventura, E., Couture, H., Fazil, A., \& Farber, J. M. (2013).Findings of the health risk assessment of Escherichia coli $\mathrm{O} 157$ in mechanically tenderized beef products in Canada. International Food Risk Analysis Journal, 3(2), 1-12.

Centers for Disease Control and Prevention, CDC. (2011). Multistate outbreak of E. coli O157:H7 infections associated with beef from National Steak and Poultry, Final Update. Retrieved from http://www.cdc.gov/ecoli/2010/ CFIA, 2013

Canadian Food Inspection Agency. (2013). Policy on the control of E. coli O157:H7/NM contamination in raw beef products: section 5.7.1. Labelling requirements for mechanically tenderized beef. Meat Hygiene Directive 2013-13-22. Retrieved from http://www.inspection.gc.ca/english/fssa/meavia/man/ch4/annexoe.shtml

Clyma, K. (2013). Washing away risk. Meat and Poultry, April, 2013, 38-41. Retrieved from http://www.meatpoultry.com/News/News\%20Home/Features/2013/4/Washing\%20away\%20risk.aspx?cck= 1

Gill, C. O., \& McGinnis, J. C. (2004). Microbiological conditions of mechanically tenderized beef cuts prepared at four retail stores. International Journal of Food Microbiology, 95, 95-102. http://dx.doi.org/10.1016/j.ijfoodmicro.2004.03.012

Gill, C. O., \& McGinnis, J. C. (2005). Factors affecting the microbiological condition of the deep tissues of mechanically tenderized beef. Journal of Food Protection, 68, 796-800.

Gill, C. O., McGinnis, J. C., Rahn, K., Young, D., Lee, N., \& Barbut, S. (2005). Microbiological condition of beef tenderized at a packing plant. Meat Science, 69, 811-816. http://dx.doi.org/10.1016/j.meatsci.2004.11.007

Gill, C. O., Moza, L. F., \& Barbut, S. (2009). Survival of bacteria in less than thoroughly cooked brine-injected steaks. Food Control, 20, 501-507. http://dx.doi.org/10.1016/j.foodcont.2008.07.019

Goodfellow, S. J., \& Brown, W. L. (1978). Fate of Salmonella inoculated into beef for cooking. Journal of Food Protection, 41, 598-605.

Jeremiah, L. E., Gibson, L. L., \& Cunningham, B. (1999). The influence of mechanical tenderization on the palatability of certain bovine muscles. Food Research International, 32, 585-591.http://dx.doi.org/10.1016/S0963-9969(99)00134-9

John, D. E., Bratcher, C. L., Kerth, C. R., \& McCaskey, T. (2011). Translocation of surface-inoculated Escherichia coli into whole muscle nonintact beef striploins following blade tenderization. Journal of Food Protection, 74, 1334-1337. http://dx.doi.org/10.4315/0362-028X.JFP-10-444 
Johnson, E. (2010). How to cook the perfect steak. The Telegraph. Retrieved from http://www.telegraph.co.uk/sponsored/foodanddrink/sainsburys-taste-the-difference/8020

Juarez, M., Klassen, M., Larsen, I. L., \& Aalhus, J. L. (2012). Canadian beef tenderness survey.Proceedings, $58^{\text {th }}$ International Congress of Meat Science and Technology, ICOMST 2012 paper 191.pdf. Retrieved from http://pubs.aic.ca/doi/full/10.4141/cjas2012-112

Laine, E. S., Scheftel, J. M., Boxrud, D. J., Vought, K. J., Danila, R. N., Elfering, K. M., \& Smith, K. E. (2005). Outbreak of Escherichia coli O157:H7 infections associated with non-intact blade-tenderized frozen steaks sold by door-to-door vendors. Journal of Food Protection, 68, 1198-1202.

Lewis, R. J., Corriveau, A., \& Usborne, W. R. (2013). Independent review of XL Foods Inc. beef recall 2012. Retrieved from http://www.foodsafety.gc.ca/english/xl_reprt-rapprte.asp

Lopez Osornio, M. M., Hough, G., Salvador, A., Chambers, V. E., McGraw, S., \& Fiszman, S. (2008). Beef's optimum internal cooking temperatures as seen by consumers from different countries using survival $\begin{array}{lllll}\text { analysis statistics. Food Quality and Preference, } & 19, & 12-20 .\end{array}$ http://dx.doi.org/10.1016/j.foodqual.2007.06.004

Luchansky, J. B., Phebus, R. K., Thippareddi, H., \& Call, J. E., (2008). Translocation of surface-inoculated Escherichia coli O157:H7 into beef subprimals following blade tenderization. Journal of Food Protection, 71, 2190-2197.

Luchansky, J. B., Porto-Fett, A. C. S., Shoyer, B., Phebus, R. K., Thippareddi, H., \& Call, J. E. (2009). Thermal inactivation of Escherichia coli $\mathrm{O} 157: \mathrm{H} 7$ in blade tenderized beef steaks cooked on a commercial open-flame gas grill. Journal of Food Protection, 72, 1404-1411.

Luchansky, J. B., Porto-Fett, A. C. S., Shoyer, B. A., Call, J. E., Schlosser, W., Shaw, W., ... Latimer, H. (2012). Fate of Shiga toxin-producing O157:H7 and non-O157:H7 Escherichia coli cells within blade-tenderized beef steaks after cooking on a commercial open flame gas grill. Journal of Food Protection, 75, 62-70. http://dx.doi.org/10.4315/0362-028X.JFP-11-267

Maddock, R. (2008). Mechanical tenderization of beef. National Cattlemen's Beef Association, Centennial, CO, USA. Retrieved from http://www.beefresearch.org/CMDocs/BeefResearch/PE_Fact_Sheets/Mechanical_Tenderization_of_Beef.p $\mathrm{df}$

Meat and Livestock Australia. (2006). Australian beef: cooking and handling. Retrieved from http://www.australian-beef.com/beef/cooking.html

Mongollon, M. A., Marks, B. P., Booren, A. M., Orta-Ramirez, A., \& Ryser, E.T. (2009). Effect of beef product physical structure on Salmonella thermal inactivation.Journal of Food Science, 74, M347-M351.

Obuz, E., Powell, T. H., \& Dikeman, M. E. (2002). Simulation of cooking cylindrical beef roasts. LWT - Food Science and Technology, 35, 637-644. http://dx.doi.org/10.1006/fstl.2002.0940

Ou, D., \& Mittal, G. S. (2008). Modeling and simulation of unfrozen hamburger single-sided panfrying with flippings for microbiological safety. Journal of Muscle Foods, 17, 115-140. http://dx.doi.org/10.1111/j.1745-4573.2006.00031.x

Patel, J. R., Williams-Campbell, A. C., Liu, M. N., \& Solomon, M. B. (2005). Effect of hydrodynamic pressure treatment and cooking on inactivation of Escherichia coli O157:H7 in blade-tenderized beef steaks. Journal of Muscle Foods, 16, 342-353. http://dx.doi.org/10.1111/j.1745-4573.2005.00026.x

Pennington, H. (2010). Escherichia coli O157:H7. Lancet, 376, 1428-1435. http://dx.doi.org/10.1016/S0140-6736(10)60963-4

Raichlen, S. (2010). Seven myths about grilling a steak. Retrieved from http://lifehacker.com/5571192/seven-myths-about-grilling-a-steak

Rhee, M. S., Lee, S. Y., Hillers, V. N., McCurdy, S. M., \& Kang, D. H. (2003). Evaluation of consumer-style cooking methods for reduction of Escherichia coli O157:H7 in ground beef. Journal of Food Protection, 66, 1030-1034.

Shen, C., Geornaras, I., Belk, K. E., Smith, G. C., \& Sofos, J. N. (2011). Inactivation of Escherichia coli O157:H7 in moisture-enhanced nonintact beef by pan-broiling or roasting with various cooking appliances set at different temperatures. Journal of Food Science, 76, M64-M71. http://dx.doi.org/10.1111/j.1750-3841.2010.01882.x 
US Department of Agriculture of Agriculture, Food Safety and Inspection Service, USDA:/FSIS. (2002). Comparative risk assessment for intact (non-tenderized) and non-intact (tenderized) beef. US Department of Agriculture: Food Safety and Inspection Service, Technical Report. Retrieved from http://www.fsis.usda.gov/wps/wcm/connect/74ebd7c2-6af2-46f2-ba20-fec1d10d4689/Beef_Risk_Assess_R eport_Mar2002.pdf?MOD=AJPERES

USDA/FSIS. (2009). FSIS guidance on safe cooking of non-intact meat chops, roasts, and steaks, April 2009. Retrieved from http://askfsis.custhelp.com/ci/fattach/get/4648/

USDA/FSIS. (2012). Descriptive designation for needle or blade tenderized (mechanically tenderized) beef products. US Department of Agriculture, Food Safety and Inspection Service, View Rule.Retrieved from https://www.federalregister.gov/articles/2013/06/10/2013-13669/descriptive-designation-for-needle--or-blad e-tenderized-mechanically-tenderized-beef-productsUSDA/FSIS, 2013.

USDA/FSIS. (2013). Compliance guideline for validating cooking instructions for mechanically tenderized beef products.US Department of Agriculture, Food Safety and Inspection Service, Guideline. Retrieved from http://www.fsis.usda.gov/wps/wcm/connect/606919b6-5192-40bd-a32b-99a41c75eeb6/Comp_Guide_MTB .pdf?MOD=AJPERES

Van Asselt, E. D., \& Zwietering, M. H. (2006). A systematic approach to determine global thermal inactivation parameters for various food pathogens. International Journal of Food Microbiology, 107, 73-82. http://dx.doi.org/10.1016/j.ijfoodmicro.2005.08.014

Velasquez, A., Breslin, T. J., Marks, B. P., Orta-Ramirez, A., Hall, N. O. Bouren, A. M., \& Ryser, E. T. (2010). Enhanced thermal resstance of Salmonellain marinated whole muscle compared with ground pork. Journal of Food Protection, 73, 372-375.

What's Cooking America. (2012). Perfect steaks - how to cook perfect steaks. What's Cooking America. Retrieved from http://whatscookingamerica.net/Beef/CookingPerfectSteak.htm

Wiegand, K. M., Ingham, S. C., \& Ingham, B. H. (2012). Evaluating lethality of beef roast cooking treatments against Escherichia coli O157:H7. Journal of Food Protection, 75, 48-61. http://dx.doi.org/10.4315/0362-028X.JFP-10-531

\section{Copyrights}

Copyright for this article is retained by the author(s), with first publication rights granted to the journal.

This is an open-access article distributed under the terms and conditions of the Creative Commons Attribution license (http://creativecommons.org/licenses/by/3.0/). 